\title{
Muscle growth and composition in heavy and light breed chickens adapted to intermittent feeding*
}

\author{
BY Y. PINCHASOV AND I. NIR \\ Department of Animal Science, Faculty of Agriculture, The Hebrew University of \\ Jerusalem, Rehovot 76-100, Israel
}

AND ZAFRIRA NITSAN

Department of Animal Science, Agricultural Research Organization, The Volcani Center, PO Box 6, Bet Dagan 50-200, Israel

(Received 5 January 1988 - Accepted 27 September 1988)

1. The effect of intermittent feeding in chickens of heavy breed (HB; meat type) and light breed (LB; egg type) on skeletal muscle growth and composition was studied in adapted and non-adapted chickens.

2. Food intake, relative to body-weight, was similar in both breeds but was higher in ad lib.-fed than in intermittently fed birds.

3. On repletion days the relative growth rate was similar in both breeds, while on depletion the LB chickens lost more weight than the HB chickens. In both breeds, the relative growth was higher in the intermittently fed birds during days of food restoration than in those fed ad lib.

4. The relative weight of the breast muscle was higher in HB birds than in LB birds, but deposition rate on the day of food restoration was similar in both breeds. This growth was more pronounced in chickens adapted to alternate feeding than in chickens exposed to this feeding regimen for one cycle.

5. Protein concentration in breast muscle was not affected by age and was slightly higher in LB chickens than in $\mathrm{HB}$ chickens. Soluble protein was markedly reduced on days of repletion, and more at $46 \mathrm{~d}$ than at $18 \mathrm{~d}$ of age.

6. The RNA : DNA ratio was higher in HB than in LB chickens, and lower on days of food deprivation than on days of food restoration. After repletion this ratio returned to the level of the ad lib.-fed chickens. While in LB chickens cell size (as estimated by DNA concentration) remained constant on repletion and depletion days, in the HB chickens it decreased.

7. The rapid growth of breast muscle in $\mathrm{HB}$ chickens was attributed to the higher rate of protein synthesis (estimated by RNA : DNA ratio) compared with LB chickens. This may also explain why the breast muscle of LB chickens was less sensitive to intermittent feeding than that of HB chickens.

Skeletal muscle, the largest tissue mass in the chicken, has an allometric relation to body growth. Ricklefs (1985) concluded from comparative studies on birds that growth rate varies among species and breeds according to adult body mass, developmental maturity at hatching, and the postnatal growth increments of skeletal leg muscles. Heavy breed (HB) chickens (meat type) have been selected for fast growth and large muscle mass, while light breed (LB) chickens (egg type), selected for other traits, have less muscle mass per unit body-weight. Selection for body mass apparently affects the rate of skeletal muscle proliferation. Differences in muscle growth rate may be associated with factors related to protein synthesis at the cell level. In order to understand the different patterns of muscle growth between these two breeds, changes in breast muscle protein, nucleic acid and fat content were analysed in LB and HB chickens.

Muscle growth rate may also be affected by age. It is commonly accepted that young animals grow relatively faster than older ones. It is also known that the relative weights of skeletal muscle increase with age (Ricklefs, 1985). From the higher rate of muscle protein increment it may be assumed that muscle growth with age has a hypertrophic rather than

* Contribution from the Agricultural Research Organization, The Volcani Center, Bet Dagan, Israel, no. $1910-\mathrm{E}, 1986$ series. 
hyperplastic growth pattern. To examine this hypothesis muscle protein and nucleic acid concentrations of $\mathrm{HB}$ and LB birds were determined relative to age.

Muscle growth rate may also be affected by meal-feeding regimen. Intermittent feeding is a programme that has been used for replacement pullets and the production of broiler breeders. The term 'meal-feeding' is commonly used with reference to animals having access to food for limited periods during the day, while intermittent feeding is used when animals are successively fed and deprived in cycles of one or more days. Generally the increase in food intake during the feeding period does not compensate for the deficit during the period of food deprivation; therefore the total food intake and body-weight gain are usually less for this feeding regimen when compared with ad lib. feeding (Nir \& Nitsan, 1979; Nitsan et al. 1984; Pinchasov et al. 1985). The rate of protein deposition in intermittently fed birds on the day of food restoration was found to be about twofold higher than that in their ad lib.-fed counterparts of LB- (Nir \& Nitsan, 1979) and HB-type chickens (Pinchasov et al. 1985). Therefore it may be assumed that the higher protein deposition observed during refeeding is associated with a higher rate of muscle protein synthesis of intermittently fed birds when compared with that of ad lib.-fed birds. This assumption was also examined in the present study by estimation of the rate of protein synthesis through changes in the concentration of skeletal muscle constituents. Since $20-30 \%$ of the total protein in muscles is in the soluble form, existing as glycolytic enzymes (Pettel \& Lebherz, 1979; Shackelford \& Lebherz, 1981), these proteins may be affected by the feeding regimen too. Adaptation to this feeding regimen was also studied by exposing chickens, fed ad lib., to one cycle of food deprivation or restoration.

In the present study we determined the effect of intermittent feeding on muscle growth and protein deposition, and investigated possible mechanisms for accelerated growth in breast muscle of broiler chickens.

\section{MATERIALS AND METHODS}

Male New Hampshire $\times$ White Leghorn LB and Cornish $\times$ White Rock HB chickens (1-d-old) were reared in battery cages. The chickens were fed on a commercial starter diet in crumble form $(216 \mathrm{~g}$ protein and $12.56 \mathrm{MJ}$ metabolizable energy $/ \mathrm{kg})$, formulated according to recommendations of the (US) National Research Council (1977). The chickens had free access to food and water until the start of the experiment.

At $12 \mathrm{~d}$ of age, chickens from each breed were divided into three treatment groups with four pens of ten chicks each arranged randomly. Birds were fed ad lib. or fed on alternate days when food was available for $24 \mathrm{~h}$ and then withheld for the next $24 \mathrm{~h}$. On any given day, three groups were available for testing, one group that had food (repleted; R), another group without food (depleted; D) and the ad lib.-fed control group (C). Body-weights and food intakes of each group were recorded daily and analysed on a pen basis (two breeds $\times$ five treatments $\times$ four pens, i.e. a total of forty pens).

Autopsies were carried out on five birds from each treatment, on days of depletion and refeeding (adapted $D$ and $R$ chicks respectively) at 18-19 $d$ of age after four cycles of intermittent feeding and at 46-47 d of age, after twelve cycles (one or two birds from each pen). On the same days control chicks which had been exposed to only one cycle of intermittent feeding (non-adapted DN and RN chicks respectively) were also autopsied. Autopsies were carried out on individual birds; five chickens per treatment from each of the two breeds at the two ages were killed by cervical dislocation (five treatments $\times$ two breeds $\times$ two ages $\times$ five birds, i.e. a total of 100 birds).

The gastrointestinal tract (GIT) was removed, emptied and its contents were weighed and subtracted from the final body-weight for the determination of empty body-weight 
(EBW; body-weight without intestinal contents). The breast (superficial pectoral) and tibia (gastrocnemieus) muscles were removed immediately, weighed, and samples were wrapped in aluminium foil and frozen in liquid nitrogen. The remainder of the breast muscles and of the muscles adhering to the tibia were carefully removed and weighed. For convenience, the tissues are referred to as 'breast or tibia muscles'.

Muscle samples were homogenized in 10 vol. ice-cold $50 \mathrm{~mm}$-potassium phosphate, 1 mM-EDTA, 1 mM-magnesium acetate, 1 mM-2-mercaptoethanol ( $\mathrm{pH} 7.5$ ) with an UltraTurrax homogenizer. Portions were drawn for the determination of $\mathrm{N}$, soluble and total protein, total lipids, RNA and DNA. Soluble protein in muscle was determined on the supernatant fraction after centrifugation of the homogenate at $12000 \mathrm{~g}$ for $15 \mathrm{~min}$ according to Pettel \& Lebherz (1979). N was determined with Nessler reagent (Association of Official Agricultural Chemists, 1965), after digestion by the micro-Kjeldhal method. Soluble and total proteins (solubilized in $0.3 \mathrm{M}$-sodium hydroxide at $37^{\circ}$ for $1 \mathrm{~h}$ ) were determined by means of the Biuret reagent (Gornall et al. 1949). RNA and DNA were determined as described by Munro \& Fleck (1969). RNA was solubilized in ice-cold 0.2 Mperchloric acid for $10 \mathrm{~min}$ and its concentration was determined from the absorption at $260 \mathrm{~nm}$. DNA was solubilized in $0.8 \mathrm{M}-\mathrm{HClO}_{4}$ at $70^{\circ}$ for $45 \mathrm{~min}$ and determined by the diphenylamine method as modified by Gills \& Meyer (1965). Total lipids were determined by the phospho-vanilin procedure (Zoellner \& Kirsch, 1962).

Electrophoresis of the soluble proteins in muscle was carried out on pooled samples from five chicks from each treatment using polyacrylamide slab gels $(90 \mathrm{~g} / \mathrm{kg}, 90 \mathrm{~mm}$ long, $1.5 \mathrm{~mm}$ thick), containing $1 \mathrm{~g}$ sodium dodecyl sulphate $/ \mathrm{kg}$ (Laemmli, 1970). The gels were stained with Coomassie blue.

The statistical analyses were carried out using the procedures of the statistical package for the social science (SPSS, Version 8; Nie et al. 1975), and the statistical analysis system (SAS Institute Inc, 1985). Values of feed intake and body-weight were analysed on a pen basis while values from autopsies were analysed for individual birds. Determination of the effect of treatment and age on growth and food intake curves (Figs. 1 and 2) was carried out using a general linear model (GLM; SAS Institute Inc, 1985), while differences between treatment means (including breed as a treatment) were assessed by Duncan's multiple range test.

The effects on muscle weight and composition (Tables 1-3) were assessed by three-way analysis of variance (ANOVA; SPSS). Differences between treatment means were assessed by Duncan's multiple range test.

\section{RESULTS}

Food intake. Average food intake was twofold higher in the HB chicks than in the LB chicks, and for each breed the intake of the intermittently fed birds was about $60 \%$ of that of the controls (Fig. 1(a)). When related to EBW (Fig. 1(b)) no significant differences between breeds for control or treated birds were noted, but the relative intake of the intermittently fed chicks was significantly lower than that of controls in both breeds.

Growth rate. Body-weight of the $\mathrm{HB}$ chicks (control and treated) was higher by about two- to threefold than that of the LB chicks, relative to age. In both breeds the EBW of the treated chicks was lower by about $30 \%$ that of the control chicks (Fig. 2(a)). The relative growth rate of the control HB chicks was significantly higher than that of the LB chicks mainly from 12 to $30 \mathrm{~d}$ of age; subsequently values were similar in both breeds. On repletion days no significant differences were found in the daily growth rates between breeds. However during depletion days the LB chicks lost on average significantly more weight $(-7.6 \%)$ than the HB chicks $(-5.8 \%)$ (Fig. $2(b)$ ).

$E B W$ and relative weight of the breast and tibia muscles. Findings of autopsies analysed 

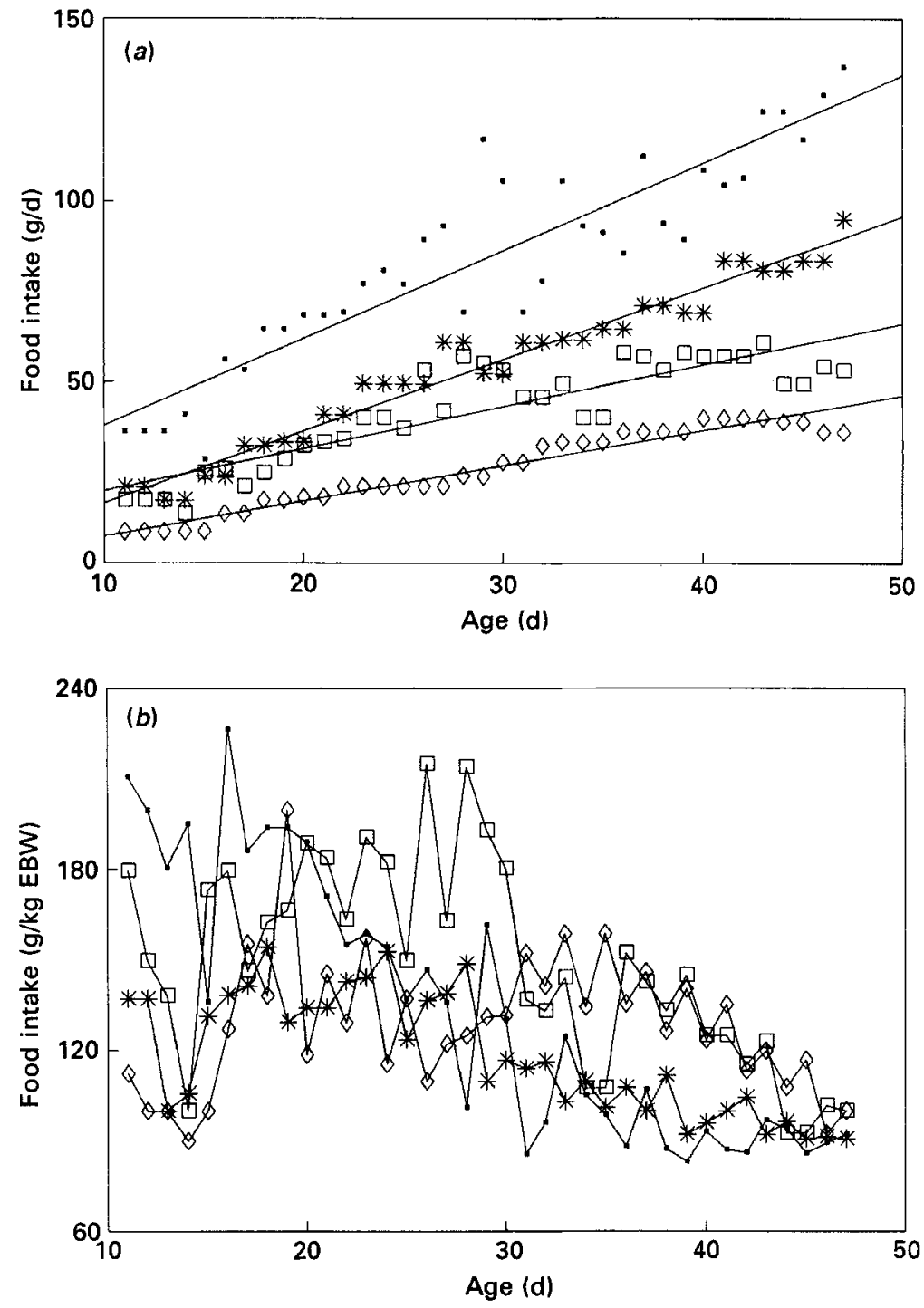

Fig. 1. Food intake $(a)(\mathrm{g} / \mathrm{d})$ and $(b)(\mathrm{g} / \mathrm{kg} ; \mathrm{EBW})$ of ad lib.- (C) and intermittently fed (IF) chickens. Heavy breed (HB): ( ) , C; (*), IF. Light breed (LB): ( $\square)$, C; (O), IF. Points represent means of four pens per treatment group.

The effect of treatment (including breed as a treatment) on food intake was assessed using a general linear model procedure, while differences between means of each curve were assessed by Duncan's multiple range test (see p. 247). Mean values from fitted curves were:

Breed...

Treatment ...

Fig. $1(a)(\mathrm{g} / \mathrm{d})$

Fig. $1(b)(\mathrm{g} / \mathrm{kg}$ EBW)
HB

\begin{tabular}{cc}
\hline C & IF \\
$84^{\mathrm{a}}$ & $54^{\mathrm{b}}$ \\
$134^{\mathrm{ab}}$ & $118^{\mathrm{c}}$
\end{tabular}

LB

\begin{tabular}{ccc}
\hline $\mathrm{C}$ & IF & SEM \\
$42^{\mathrm{c}}$ & $26^{\mathrm{a}}$ & $1 \cdot 7$ \\
$148^{\mathrm{a}}$ & $128^{\mathrm{be}}$ & $2 \cdot 6$
\end{tabular}

a, b,c,d, For means with different superscript letters there were significant differences between treatment groups and breeds $(P<0 \cdot 05)$. 

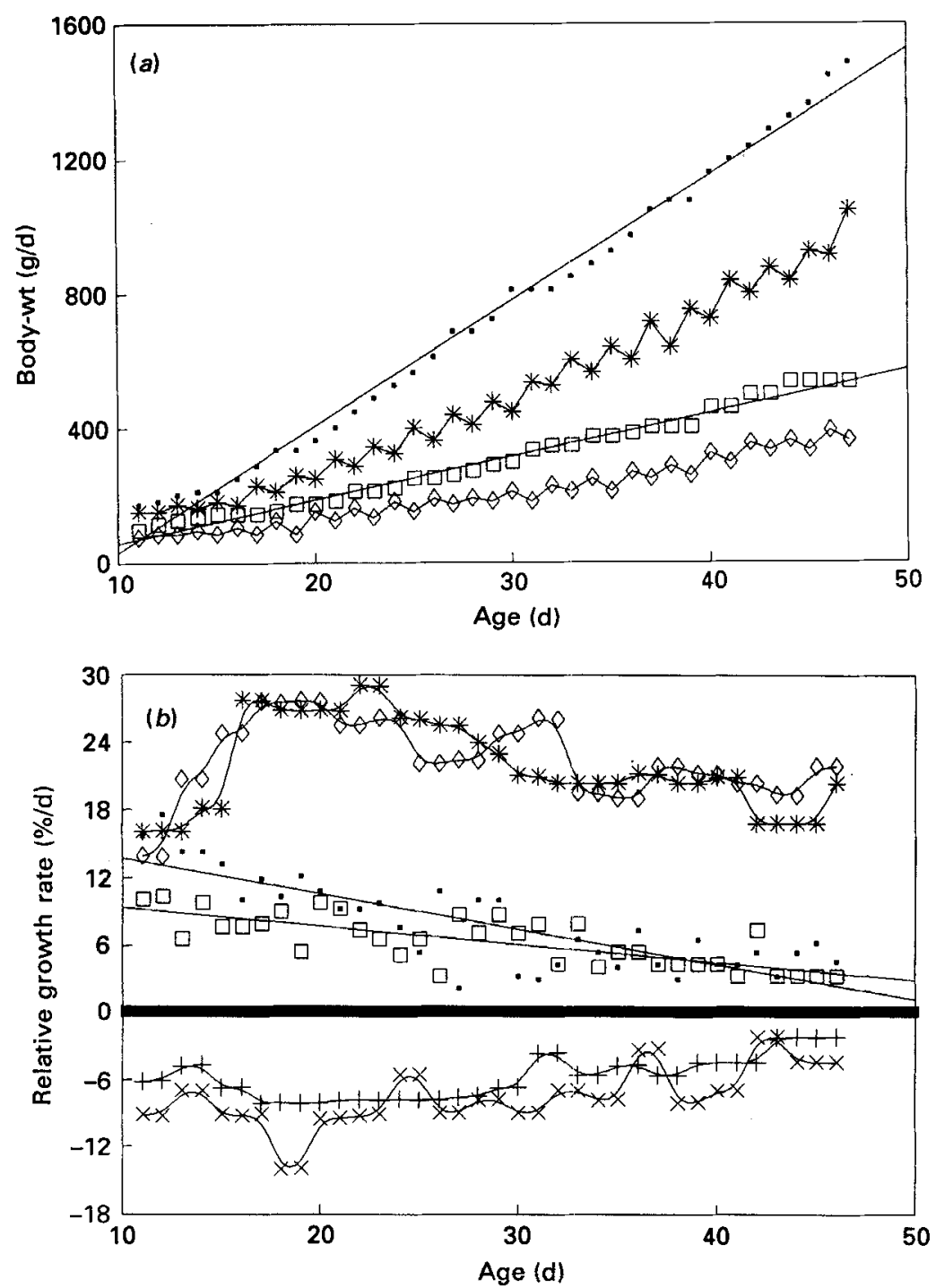

Fig. 2. (a) Empty body-weight (g) and (b) relative growth rate (\%/d) of ad lib.- (C) and intermittently fed birds after depletion (D) or repletion (R) days in heavy breed (HB) and light breed (LB) chickens. HB: $(\bullet), C ;(+), D ;\left(^{*}\right)$, R. LB : $(\square), C ;(\times), D ;(\diamond)$, R. Points represent means of four pens per treatment group.

The effect of treatment (including breed as a treatment) on growth curves was assessed using a general linear model procedure, while differences between means of each curve were assessed by Duncan's multiple range test (see p. 247). Mean values from fitted curves were:

Breed...

Treatment...

Fig. $1(a)(\mathrm{g} / \mathrm{d})$

Fig. $1(b)(\% / d)$
HB

\begin{tabular}{ccc}
\hline C & D & R \\
$740^{\mathrm{a}}$ & - & $492^{\mathrm{b}}$
\end{tabular}

LB

\begin{tabular}{cccc}
\hline $\mathrm{C}$ & $\mathrm{D}$ & $\mathrm{R}$ & SEM \\
$302^{\mathrm{c}}$ & - & $204^{\mathrm{d}}$ & 21 \\
$6.3^{\mathrm{c}}$ & $-7 \cdot 6^{\mathrm{e}}$ & $23^{\mathrm{a}}$ & 0.22
\end{tabular}

a, b, e, d For means with different superscript letters there were significant differences between treatment groups and breeds $(P<0.05)$. 
Table 1. Empty body-weight (EBW) and breast and tibia relative weights in heavy (HB) and light $(L B)$ breeds of birds at 18 and $46 d$ of age within treatment groups

(Mean values with their standard errors for five birds for each treatment within ages and breeds)

\begin{tabular}{|c|c|c|c|c|c|c|c|c|}
\hline \multirow{2}{*}{$\begin{array}{l}\text { Age } \\
\text { (d) }\end{array}$} & \multirow[b]{2}{*}{ Breed } & \multirow[b]{2}{*}{ Treatment } & \multicolumn{2}{|c|}{$\begin{array}{c}\mathrm{EBW}^{*} \\
(\mathrm{~g})\end{array}$} & \multicolumn{2}{|c|}{$\begin{array}{c}\text { Breast } \\
(\mathrm{g} / \mathrm{kg} \mathrm{EBW})\end{array}$} & \multicolumn{2}{|c|}{$\begin{array}{c}\text { Tibia } \\
\text { (g/kg EBW) }\end{array}$} \\
\hline & & & Mean & $\mathrm{SE}$ & Mean & $\mathrm{SE}$ & Mean & $\mathrm{SE}$ \\
\hline 18 & $\mathrm{HB}$ & $\begin{array}{c}\text { C } \\
\text { DN } \\
\text { RN } \\
\text { D } \\
\text { R } \\
\text { Mean }\end{array}$ & $\begin{array}{l}297^{\mathrm{a}} \\
250^{\mathrm{b}} \\
293^{\mathrm{a}} \\
196^{\mathrm{c}} \\
238^{\mathrm{b}} \\
255\end{array}$ & $\begin{array}{r}13 \\
10 \\
9 \\
10 \\
14\end{array}$ & $\begin{array}{l}125^{\mathrm{ab}} \\
137^{\mathrm{a}} \\
125^{\mathrm{ab}} \\
119^{\mathrm{b}} \\
120^{\mathrm{b}} \\
125\end{array}$ & $\begin{array}{l}4 \\
3 \\
4 \\
5 \\
7\end{array}$ & $\begin{array}{l}38 \\
38 \\
38 \\
39 \\
37 \\
38\end{array}$ & $\begin{array}{l}1 \\
1 \\
1 \\
1 \\
2\end{array}$ \\
\hline 18 & LB & $\begin{array}{c}\text { C } \\
\text { DN } \\
\text { RN } \\
\text { D } \\
\text { R } \\
\text { Mean }\end{array}$ & $\begin{array}{c}131^{\mathrm{a}} \\
110^{\mathrm{b}} \\
127^{\mathrm{a}} \\
90^{\mathrm{c}} \\
111^{\mathrm{b}} \\
114\end{array}$ & $\begin{array}{l}4 \\
3 \\
6 \\
3 \\
4\end{array}$ & $\begin{array}{l}120 \\
112 \\
114 \\
106 \\
107 \\
112\end{array}$ & $\begin{array}{l}5 \\
5 \\
4 \\
7 \\
5\end{array}$ & $\begin{array}{l}38 \\
36 \\
37 \\
37 \\
35 \\
37\end{array}$ & $\begin{array}{l}2 \\
1 \\
1 \\
1 \\
1\end{array}$ \\
\hline 46 & HB & $\begin{array}{c}\text { C } \\
\text { DN } \\
\text { RN } \\
\text { D } \\
\text { R } \\
\text { Mean }\end{array}$ & $\begin{array}{c}1455^{\mathrm{a}} \\
1266^{\mathrm{ab}} \\
1371^{\mathrm{a}} \\
923^{\mathrm{c}} \\
1069^{\mathrm{b}} \\
1217\end{array}$ & $\begin{array}{l}87 \\
89 \\
91 \\
26 \\
28\end{array}$ & $\begin{array}{l}171^{\mathrm{ab}} \\
175^{\mathrm{a}} \\
172^{\mathrm{ab}} \\
160^{\mathrm{b}} \\
154^{\mathrm{b}} \\
166\end{array}$ & $\begin{array}{l}3 \\
3 \\
6 \\
3 \\
4\end{array}$ & $\begin{array}{l}47 \\
52 \\
48 \\
52 \\
49 \\
50\end{array}$ & $\begin{array}{l}7 \\
1 \\
1 \\
1 \\
1\end{array}$ \\
\hline 46 & LB & $\begin{array}{c}\text { C } \\
\text { DN } \\
\text { RN } \\
\text { D } \\
\text { R } \\
\text { Mean }\end{array}$ & $\begin{array}{l}513^{\mathrm{a}} \\
463^{\mathrm{b}} \\
478^{\mathrm{ab}} \\
338^{\mathrm{c}} \\
472^{\mathrm{ab}} \\
453\end{array}$ & $\begin{array}{r}19 \\
14 \\
25 \\
8 \\
12\end{array}$ & $\begin{array}{l}140^{\mathrm{ab}} \\
148^{\mathrm{a}} \\
141^{\mathrm{ab}} \\
133^{\mathrm{b}} \\
131^{\mathrm{b}} \\
132\end{array}$ & $\begin{array}{l}5 \\
8 \\
7 \\
2 \\
2\end{array}$ & $\begin{array}{l}47^{\mathrm{ab}} \\
50^{\mathrm{a}} \\
48^{\mathrm{ab}} \\
46^{\mathrm{b}} \\
44^{\mathrm{b}} \\
47\end{array}$ & $\begin{array}{l}1 \\
3 \\
1 \\
1 \\
2\end{array}$ \\
\hline
\end{tabular}

C, ad lib.- fed control; non-adapted birds to intermittent feeding: DN, depleted; RN, repleted; adapted birds to intermittent feeding: D, depleted; $R$, repleted; for details of treatments, see p. 246.

a.b,c Means with different superscript letters within age and breed, differed significantly $(P<0.05)$.

* Live body-weight less gastrointestinal content.

at 18 and $46 \mathrm{~d}$ of age revealed that EBW was affected by age, breed and treatment. A statistically significant interaction was obtained between these three main effects (Table 3 , p. 252). In non-adapted depleted birds (DN, Table 1) food removal for $24 \mathrm{~h}$ was accompanied by a depression of EBW, which almost returned to the weight of the control chicks following $24 \mathrm{~h}$ of food restoration (RN). The average increment after food restoration was about twofold higher in adapted than in non-adapted birds.

The relative weight of the breast muscle was significantly higher in HB chicks than in LB chicks for all treatment groups at 18 and $46 \mathrm{~d}$ of age (Tables 1 and 3). It increased with age, more in HB chicks than in the LB chicks, from approximately 12 to $17 \%$ and from 12 to $14 \%$ of EBW respectively. The relative weight of breast muscle in the adapted chicks was lower than that of the non-adapted chicks for both breeds. The deposition of breast muscle on the day of food restoration decreased with age and, as for EBW, was higher in adapted than in non-adapted birds (comparing breast muscle weight $(\mathrm{g})$ values using the repleted:depleted ratio, calculated from values in Table 1).

The relative weight of the tibia muscle increased with age by about $20 \%$ in both breeds (Table 1). A slightly higher relative tibia weight was found in HB chicks compared with LB 
Muscle growth in intermittently fed chicks

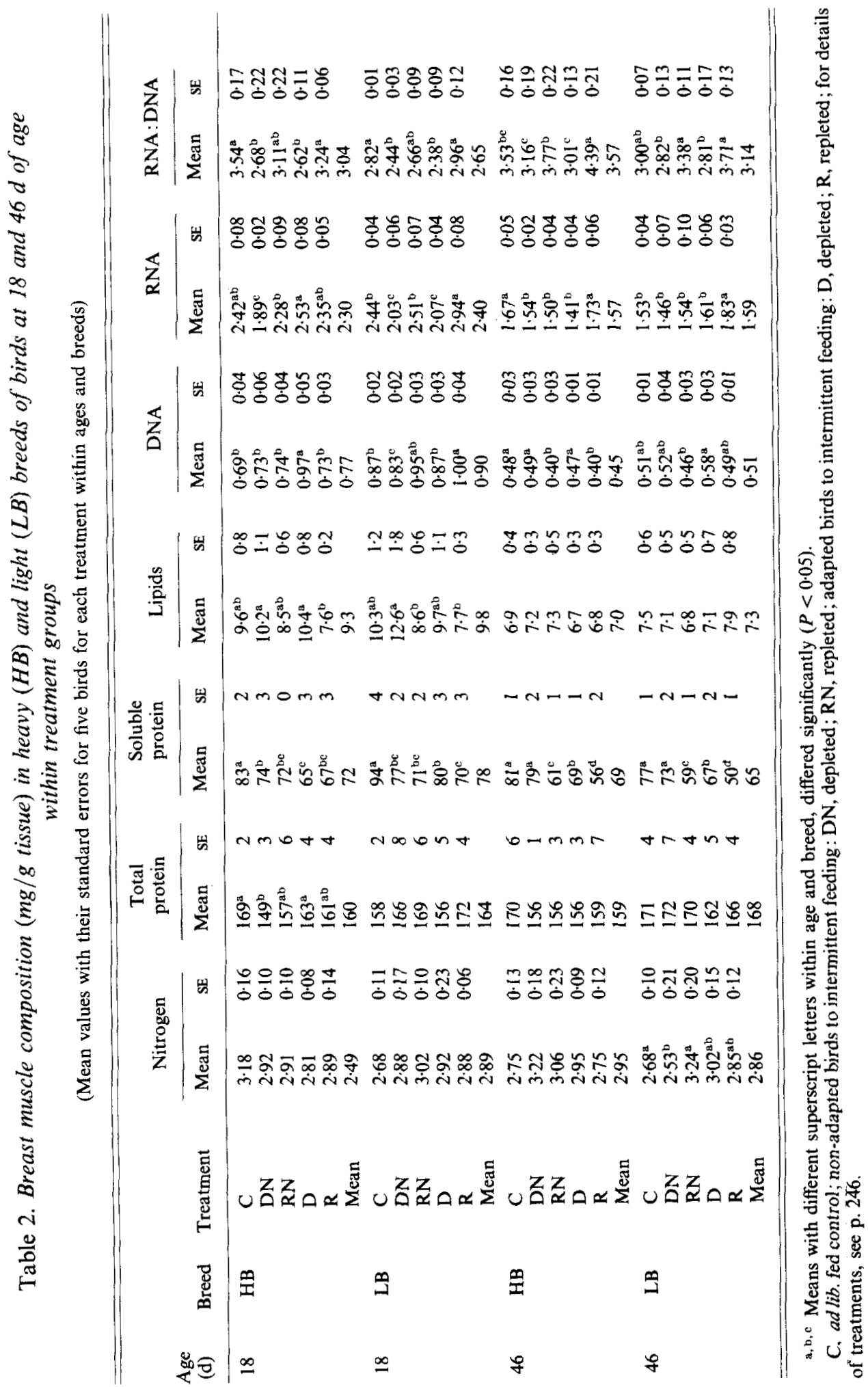


Table 3. Main effects of age, breed, treatment and their interactions from the values presented in Tables 1 and 2

(Values from five treatments with five birds each, two ages and two breeds, a total of 100 birds randomly arranged using ANOVA)

\begin{tabular}{|c|c|c|c|c|c|c|c|}
\hline & \multicolumn{3}{|c|}{ Main effect } & \multicolumn{4}{|c|}{ Interactions } \\
\hline & Age & Breed & Treatment & $\mathbf{A B}$ & AT & BT & ABT \\
\hline & ** & $* *$ & *** & ** & ** & ** & ** \\
\hline \multicolumn{8}{|l|}{ Breast wt } \\
\hline (g/kg EBW) & ** & $* *$ & ** & $* *$ & NS & NS & NS \\
\hline \multicolumn{8}{|l|}{ Tibia wt } \\
\hline \multicolumn{8}{|c|}{ Breast composition (Table 2) (mg/kg EBW) } \\
\hline $\begin{array}{l}\text { Nitrogen } \\
\text { Protein }\end{array}$ & NS & NS & NS & NS & NS & * & NS \\
\hline Total & NS & ** & NS & NS & NS & ** & NS \\
\hline Soluble & $* *$ & NS & $* *$ & $* *$ & $* *$ & $*$ & NS \\
\hline Lipids & $* *$ & NS & $* *$ & NS & ** & NS & NS \\
\hline DNA & $* *$ & $* *$ & $* *$ & $*$ & $* *$ & $* *$ & $* *$ \\
\hline RNA & $* *$ & $* *$ & ** & NS & ** & $* *$ & $* *$ \\
\hline RNA : DNA & $* *$ & $* *$ & $* *$ & NS & ** & NS & NS \\
\hline
\end{tabular}

NS, not significant $(P>0.05) ; \mathrm{AB}$, age $\times$ breed; AT, age $\times$ treatment; BT, breed $\times$ treatment; ABT, age $\times$ breed $\times$ treatment.

* $P<0.05, \quad * * P<0.01, \quad * * * P<0.001$.

chicks. Intermittent feeding did not significantly affect the relative weight of the tibia muscle.

Breast muscle composition. Most of the breast muscle components measured (total $\mathrm{N}$ excepted) were affected by age, breed and treatment (Table 3).

Total protein concentration was not affected by age or treatment, but it was significantly higher in the LB chicks than in HB chicks, mainly at $46 \mathrm{~d}$ of age (Tables 2 and 3). Soluble protein concentration decreased with age more consistently in the LB chicks than in the HB chicks, with no significant differences between breeds. The soluble-protein concentration was higher in the control birds than in any of the other treated chicks. In the $R$ and $R N$ birds, soluble protein concentration was lower than in the D and DN chicks (except for D in $\mathrm{HB}$ at $18 \mathrm{~d}$ ).

Lipid concentrations in breast muscle decreased slightly with age to the same extent in both breeds (Table 3). At $18 \mathrm{~d}$ of age, lipid content was higher in $\mathrm{D}$ than in $\mathrm{R}$ and in $\mathrm{DN}$ than in RN chicks. No significant trend was noted at $46 \mathrm{~d}$ of age.

The concentration of the DNA decreased with age in both breeds. It was higher in the LB than in the HB chicks at both ages (Tables 2 and 3). RNA was also reduced with age and was slightly higher in the LB chicks at $18 \mathrm{~d}$ of age but not at $46 \mathrm{~d}$ of age. Intermittent feeding affected the concentration of RNA and DNA in both lines. At $46 \mathrm{~d}$ of age, DNA concentration was higher in $\mathrm{D}$ than in $\mathrm{R}$ chicks of both breeds, but at $18 \mathrm{~d}$ this trend was noted in HB chicks only. In the LB chicks, RNA concentration was lower in D and DN than in $R$ and $R N$ chicks at both ages. In HB chicks, the increase in RNA concentration following food restoration was not consistent. The increment in RNA content between depletion and repletion days was greater in the adapted birds than in the non-adapted birds (except HB at $18 \mathrm{~d}$ of age; Table 2).

The RNA:DNA ratio was higher in the HB chicks than in the LB chicks (Table 3) at 
both ages. It was lower in D than in R chicks and in DN than in RN chicks of both breeds and at both ages. After repletion the RNA:DNA ratio was similar to, or larger than, that found in control chicks (Table 2).

Electrophoresis of the breast muscle soluble protein. An electrophoretogram of the soluble proteins in breast muscle showed fourteen clear bands. Two of them were identified according to Pettel \& Lebherz (1979) as myofibril proteins (myosin (no. 1) and actin (no. 7)), and five were identified as glycolytic enzymes (nos. 3, 6, 9, 10, 14). At $46 \mathrm{~d}$ of age after food restoration in both breeds, fraction nos. 1-4 and 9 were diminished dramatically (Plate 1). This phenomenon was not observed at $18 \mathrm{~d}$ of age.

\section{DISCUSSION}

Age effects. During the period of early growth, the breast and leg muscle develop at a faster rate than the rest of the chick's body (Sunde et al. 1984; Jones et al. 1986). This finding was confirmed in the present study, since the relative weight of the breast muscle increased with age in both breeds (Table 1). Although the EBW of HB chicks was higher than that of the LB chicks throughout the experimental period (Fig. 2(a)), the relative growth rate of the ad lib.-fed HB chicks was higher only up to $30 \mathrm{~d}$ of age (Fig. 2(b)). This finding is in accord with the approach that the superiority of HB chicks in body-weight is a result of a higher relative growth rate at an early age (about $2-4$ weeks), and that this higher rate may be the primary factor responsible for the differences in body-weights among breeds (Burke \& Marks, 1982; Nir et al. 1987).

The increase in the relative weight of the breast and tibia muscles with age (Table 1) is at the expense of the decrease in the GIT relative weight with age, which is more pronounced in HB chicks than in LB chicks (Nir \& Nitsan, 1979; Pinchasov et al. 1985). Moreover, the higher relative weight of the GIT in intermittently fed birds than in those fed ad lib. is in accordance with the lower relative weight of the breast muscle found in treated chicks in the present work. In spite of the rapid growth rate of the skeletal muscle mass with age in both breeds, a constant total protein concentration was maintained in the muscle tissue, while the soluble protein was slightly reduced (Tables 1 and 2). It seems, therefore, that the fibral protein increased with age.

The slight reduction in the lipid content of breast muscle with age is in accordance with the findings of Grey et al. (1983), who reported a slight decrease in fat content in breast and thigh tissues from 35 to $76 \mathrm{~d}$ of age. This was presumably related to a decrease in cell membrane mass, since most of the lipids in muscles are located in the myofibril membrane. The superiority of hypertrophic over hyperplastic growth with age, as shown by the reduction in nucleic acid concentration, confirms this hypothesis. Hentges et al. (1983) also showed a reduction in nucleic acid content with age in different strains of chicks.

Breed effects. It is generally believed that selection for increased rate of growth is associated with excessive fat deposition in broilers. Selection for rapid juvenile growth is accompanied by correlated changes in appetite (Cherry et al. 1987), feeding behaviour (Dunnington et al. 1987), GIT weight (Cherry et al. 1987), muscle protein deposition (Fisher, 1980; Hentges et al. 1983; Ricklefs, 1985) and other metabolic activities (Nir et al. 1987; Nitsan et al. 1984; Siegel, 1984). In the present work another correlated response has been described: muscle growth and muscle composition. The relative weight of the skeletal muscles in the HB chicks was markedly greater than that of the LB chicks (by $16 \%$ ) and the cells were larger, as indicated by the $16 \%$ lower DNA concentration (Table 1). Although the $14 \%$ increase in the RNA:DNA ratio indicated a higher protein synthesis in HB chicks than in LB chicks, it seems that the enhanced synthesis was not sufficient to compensate for the rapid growth of the breast muscle; therefore, protein concentration was 

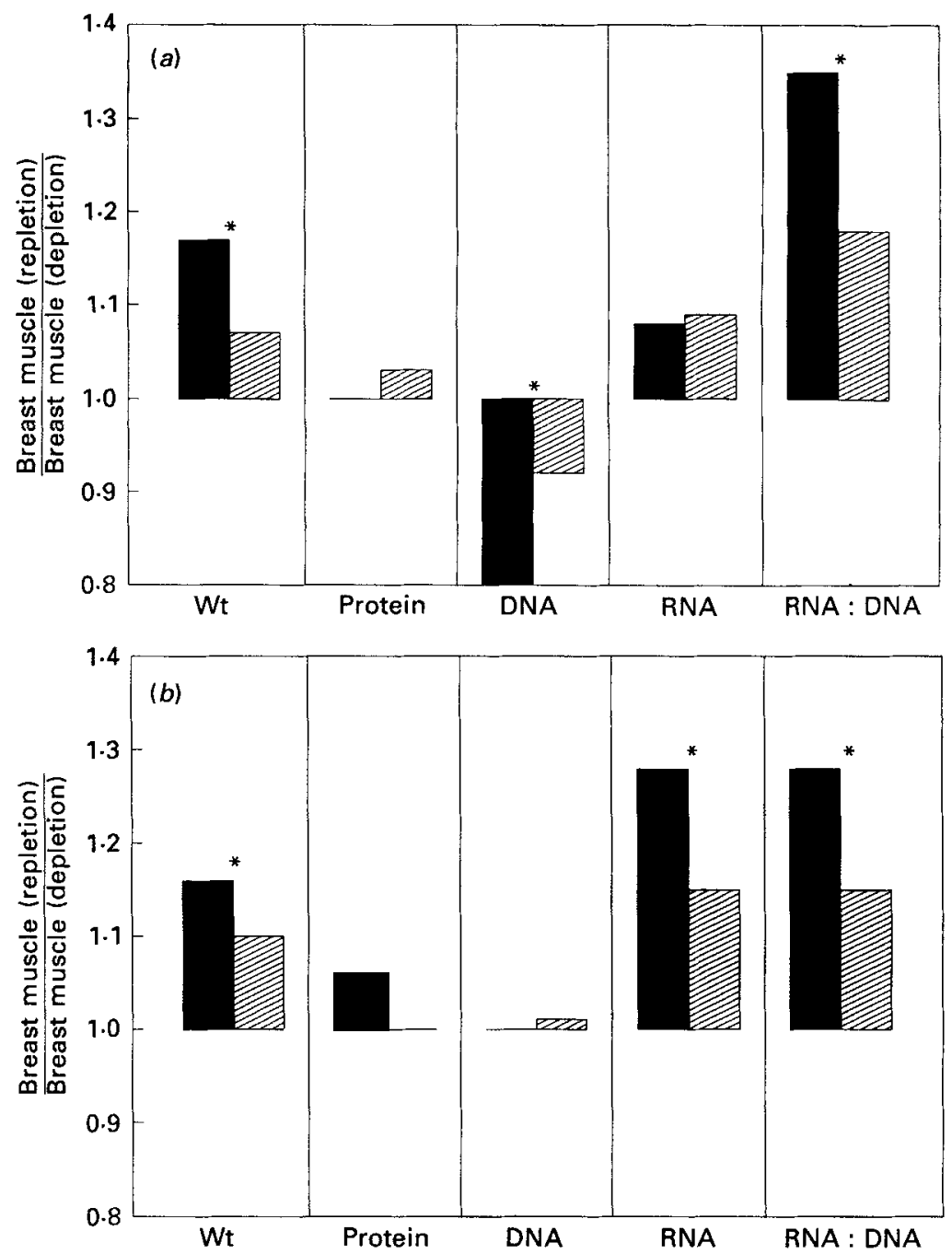

Fig. 3. The ratios in breast muscle weight and its composition between repletion and depletion days in adapted $(\square)$ or non-adapted (沙) intermittent feeding of $(a)$ heavy and $(b)$ light breeds. Means of two ages (ten birds each column).

* Significant differences between adapted and non-adapted birds $(P<0.05)$.

slightly lower in the HB chicks than in the LB chicks. This finding is in accord with observations in Japanese quails (Coturnix coturnix japonica) selected for rapid growth (Fowler et al. 1980).

Treatment effects. The rate of protein deposition in intermittently fed birds on the day of food restoration was found to be about twofold higher than in ad lib.-fed counterparts in LB (Nir \& Nitsan, 1979) and HB (Pinchasov et al. 1985) chicks. The enhanced breast muscle growth on days of food restoration was considerably higher in adapted than in nonadapted control chicks. However this compensatory growth was not sufficient to compensate for the degradation on days of food deprivation. Therefore in the intermittently fed chicks the weight of the breast was smaller, but the total protein concentration remained constant. 
The soluble protein was the main fraction affected by the treatments. In intermittently fed birds (D, DN, R, RN) the concentration of the soluble protein was significantly lower than that in the control birds (Table 2), and reduced by about $30 \%$ on days of food restoration as compared with days of food deprivation. This decrease was age-dependent, since it was more pronounced at $46 \mathrm{~d}$ of age than at $18 \mathrm{~d}$ of age (Table 2). The length of the adaptation period to intermittent feeding could also be related to the previously specified age differences. The major part of the soluble protein is the glycolytic enzymes (Shackelford \& Lebherz, 1981), which are involved in protein and energy metabolism. Due to metabolic adaptation the level of these enzymes decreased markedly on days of food restoration, when exogenous sources of protein and energy were ample. On days of food deprivation these enzymes were restored to enable the utilization of endogenous protein and energy sources. The short-term adaptation to the feeding regimen is emphasized by this phenomenon.

Although the increase in the breast muscle weight and in the RNA:DNA ratio on the day of food restoration was higher in adapted than in non-adapted chicks, the pattern of this growth differed between breeds (Fig. 3). In the LB chicks, apparently cell size did not differ between $\mathrm{D}$ and $\mathrm{R}$ chicks and between DN and RN chicks, as indicated by the constant DNA concentration. In the HB chicks food restoration was accompanied by an increase in cell size. Since DNA concentration was reduced by food restoration, this reduction was more pronounced in the adapted than in the non-adapted birds (Fig. 3).

The changes in RNA concentration due to food restoration are in accord with the previously mentioned findings: a smaller increase was noted in the HB chicks than in the LB chicks, in which presumably the cell size did not increase. It was reported that LB chicks are less susceptible to intermittent feeding than HB chicks, since in LB chicks body-weight and body fat content were less affected than in $\mathrm{HB}$ chicks by intermittent feeding (Pinchasov et al. 1985; Nir et al. 1987). In the present work it was shown that muscle composition and cell size are also less affected by intermittent feeding in LB compared with HB chicks.

The authors thank Mrs M. Barak and Mrs Z. Zoref for technical assistance. This research was supported by grant no. US 675-83C from the US-Israel Binational Agricultural Research and Development Fund (BARD).

\section{REFERENCES}

Association of Official Agricultural Chemists (1965). Official Methods of Analysis, 10th ed., p. 605. Washington, DC: Association of Official Agricultural Chemists.

Burke, W. H. \& Marks, H. L. (1982). Growth hormone and prolactin levels in non-selected and selected broiler lines of chickens from hatch to eight weeks of age. Growth 46, 283-295.

Cherry, J. A., Nir, I., Jones, D. E., Dunnington, E. A., Nitsan, Z. \& Siegel, P. B. (1987). Growth-associated traits in parental and $\mathrm{Fl}$ populations of chickens under different feeding programs. 1. ad libitum feeding. Poultry Science 67, 1-9.

Dunnington, E. A., Nir, I., Cherry, J. A., Jones, D. E. \& Siegel, P. B. (1987). Growth-associated traits in parental and $F 1$ populations of chickens under different feeding programs. 3. Behavior and body temperature. Poultry Science 67, 23-31.

Fisher, C. (1980). Protein deposition in poultry. In Protein Deposition in Animals, pp. 251-270 [P. J. Buttery and D. B. Lindsay, editors]. London: Butterworths.

Fowler, S. P., Campion, D. R., Marks, H. L. \& Reagan, J. O. (1980). An analysis of skeletal muscle response to selection for rapid growth in Japanese quail (Coturnix coturnix japonica). Growth 44, 235-252.

Gills, K. W. \& Meyer, A. (1965). An improved diphenylamine method for the estimation of DNA. Nature 206, 96.

Gornall, A. G., Bardawill, E. J. \& David, M. M. (1949). Determination of serum protein by means of biuret reaction. Journal of Biological Chemistry 177, 751-766.

Grey, T. C., Robinson, D., Jones, J. M., Stock, S. W. \& Thomas, N. L. (1983). Effect of age and sex on the composition of muscle and skin from a commercial broiler strain. British Poultry Science 24, 219-231. 
Hentges, E. L., Marple, D. N., Roland, D. A. \& Pritchett, J. F. (1983). Growth and in vitro protein synthesis in two strains of chicks. Journal of Animal Science 57, 320-327.

Jones, S. J., Judge, M. D. \& Aberle, E. D. (1986). Muscle protein turnover in sex-linked dwarf and normal broiler chickens. Poultry Science 65, 2082-2089.

Laemmli, U. K. (1970). Cleavage of structural protein during the assembly of the head of bacteriophage T4. Nature 227, 680-685.

Munro, H. N. \& Fleck, A. (1969). Analysis of tissue and body fluids for nitrogenous constituents. In Mammalian Protein Metabolism, vol. 3, pp. 423-525 [H. N. Munro, editor]. New York: Academic Press.

National Research Council (1977). Nutrient Requirements of Poultry, 7th ed. Washington, DC: National Academy of Science.

Nie, N. H., Hull, C. H., Jenkins, J. G., Steinbrenner, K. \& Bent, D. H. (1975). Statistical Package for the Social Sciences, 2nd ed. New York: McGraw-Hill Book Company.

Nir, I., Harvey, S., Cherry, J. A., Dunnington, E. A., Klandorf, H. \& Siegel, P. B. (1987). Growth-associated traits in parental and $F 1$ populations of chickens under different feeding programs. 4. Growth and thyroid hormones. Poultry Science 67, 32-40.

Nir, I. \& Nitsan, Z. (1979). Metabolic and anatomical adaptation of light bodied chicks to intermittent feeding. British Poultry Science 20, 61-71.

Nitsan, Z., Nir, I. \& Petihi, I. (1984). The effect of meal-feeding and food restriction, food utilization and intestinal adaptation in light-breed chicks. British Journal of Nutrition 51, 101-109.

Pettel, J. K. \& Lebherz, H. G. (1979). Regulation of fructose diphosphate aldolase concentration in skeletal muscle of normal and dystrophic chickens. Journal of Biological Chemistry 254, 7411-7417.

Pinchasov, Y., Nir, I. \& Nitsan, Z. (1985). Metabolic and anatomical adaptation of heavy chicks to intermittent feeding. I. Food intake, growth rate, organ weight and body composition. Poultry Science 64, $2098-2109$.

Ricklefs, R. E. (1985). Modification of growth and development of muscles of poultry. Poultry Science 64, $1563-1576$.

SAS Institute Inc. (1985). SAS User's Guide: Statistics, Version 5 ed. Cary, NC: SAS Institute Inc.

Shackelford, J. E. \& Lebherz, H. L. (1981). Effect of denervation on the levels and rates of synthesis of specific enzymes in 'fast-twitch' (breast) muscle fibers of the chicken. Journal of Biological Chemistry 256, 6423-6429.

Siegel, P. B. (1984). Factors influencing excessive fat deposition in meat poultry. 1. Genetic. In Proceedings of the XVII World's Poultry Congress, Helsinki, pp. 51-52. Kirjapaino Auranen, Forssa: Finish Branch of WPSA.

Sunde, M. L., Swick, R. W. \& Kang, C. K. (1984). Protein degradation: an imported consideration. Poultry Science 63, 2055-2061.

Zoellner, N. \& Kirsch, K. (1962). Determination of lipids (micromethod) by means of the sulfophosphovanillin reaction common to many natural lipids (all known plasma lipids). Zeitschrift für die Gesamte Experimental Medicine 135, 545-556.

\section{EXPLANATION OF PLATE}

Plate 1. Electrophoretogram of soluble proteins in breast muscle of chickens from heavy and light breeds at 18 and $46 \mathrm{~d}$ of age. C, ad lib.-fed control; non-adapted birds to intermittent feeding: DN, depleted; RN, repleted; adapted birds to intermittent feeding: D, depleted; R, repleted. For details of treatments, see p. 246.

Values are for pooled samples from five birds per treatment. Identity of the proteins was determined by comparison of the protein bands with those shown by Shackelford \& Lebherz (1981). 1, Myosin: 3, phosphorylase $(E C 2.4 .1 .1)$; 6, enolase $(E C 4.2 .1 .11) ; 7$, actin; 8, creatine kinase $(E C 2.7 .3 .2)$; 9, fructose-bisphosphate aldolase (EC 4.1.2.13); 10, glyceraldehyde 3-phosphate dehydrogenase $(E C$ 1.2.1.12); 14, phosphoglyceromutase (EC 5.4.2.1). 
British Journal of Nutrition, Vol. 61 No. 2

Plate 1
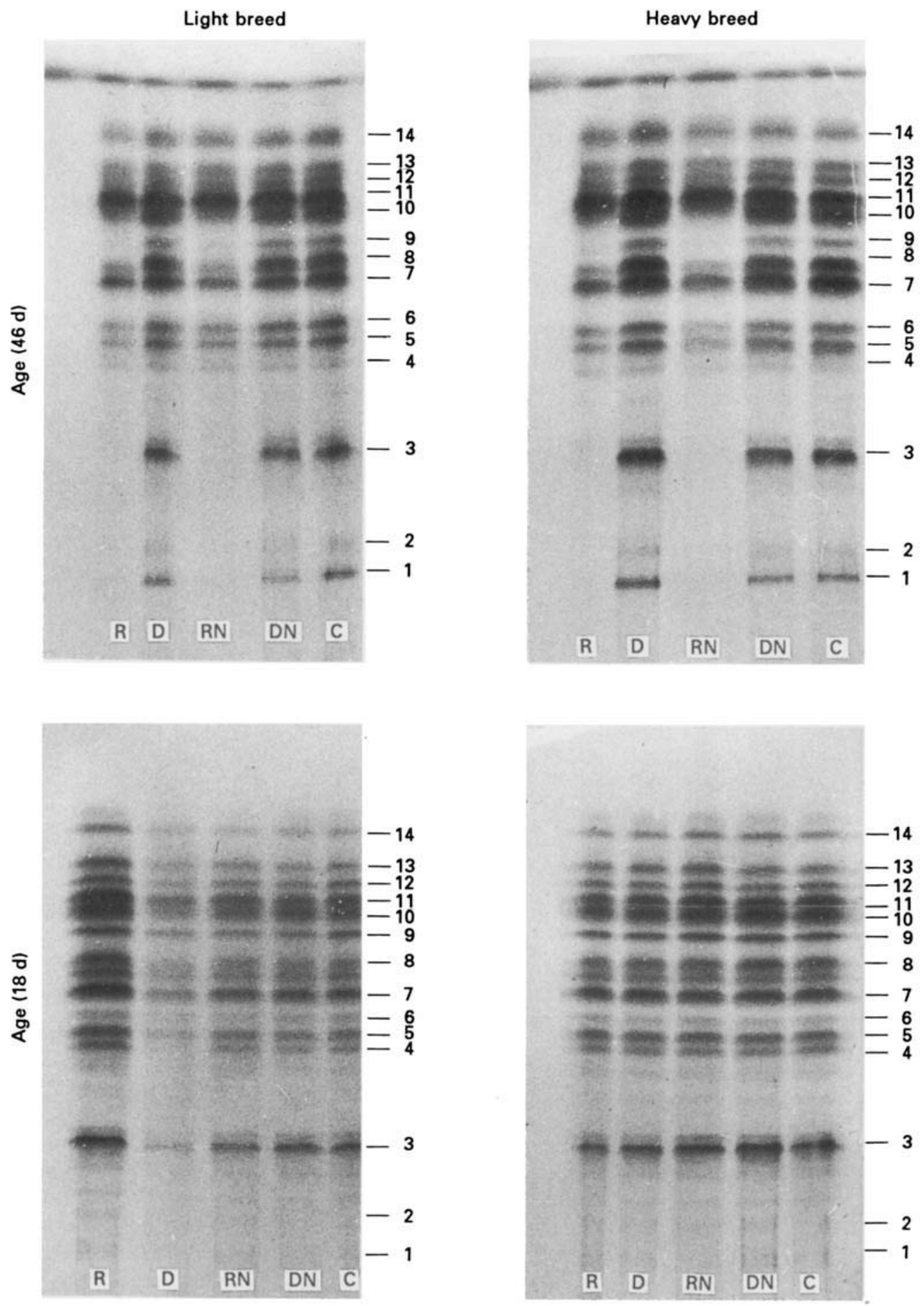